\title{
NOTAS SOBRE A FUNÇÃO DO ESTADO NO LIVRO I DE O CAPITAL
}

\author{
Notes on the function of State on Marx Volume One of The Capital
}

SARTORI, Vitor Bartoletti ${ }^{1}$

\section{RESUMO}

Tendo como pano de fundo a teorização sobre a determinação ontonegativa da politicidade, de José Chasin, pretendemos neste pequeno artigo realizar a análise imanente do livro I de $\mathrm{O}$ capital. Para tanto, trataremos das determinações gerais da política na mencionada obra marxiana. Intenta-se mostrar como que o papel ativo do Estado e do Direito tem grande importância na obra de Karl Marx. Assim, há de se ver como que este fato traz à tona, ao mesmo tempo, o modo complexo pelo qual deve ser entendida a questão da determinação econômica.

Palavras-chave: Marx. Livro I de O capital. Estado. Direito.

\section{ABstract}

Having as the background the theory of José Chasin, on the ontonegative determination of politics, we intend in this article to carry out the immanent analysis of Volume I of Capital. We shall deal with the general determinations of politics in the aforementioned Marxian work. It is intended to show how the active role of the State and Law plays a major role in the work of Karl Marx. Thus it must be seen that this fact brings out at the same time the complex mode by which the question of economic determination must be understood.

Keywords: Marx. Volume I of The Capital. State. Right

\footnotetext{
1 Professor adjunto na Faculdade de Direito e Ciências do Estado da UFMG. Mestre em História pela PUC-SP, Doutor em Filosofia do Direito pela USP. E-mail: vitorbsartori@gmail.com.
} 
O que melhor poderia caracterizar o modo de produção capitalista do que a necessidade de que the sejam impostas, por meio de coação legal do Estado, as mais simples providências de higiene e saúde? (MARX, Karl. O Capital, Livro I, Volume II. Trad. Regis Barbosa e Flávio R. Kothe São Paulo: Nova Cultural, 1996 b, p. 110)

O capital, assim que fica sujeito ao controle do Estado apenas em alguns pontos da periferia social, se ressarce tanto mais desmesuradamente nos outros pontos; segundo, o clamor dos próprios capitalistas por igualdade nas condições de concorrência, isto é, limitações iguais à exploração do trabalho. (MARX, Karl. O Capital, Livro I, Volume II. Trad. Regis Barbosa e Flávio R. Kothe São Paulo: Nova Cultural, 1996 b, p. 118)

\section{INTRODUÇÃO}

No presente artigo, procuraremos analisar o papel que tem a violência estatal no livro I de O capital de Karl Marx. Intentamos abordar o tema ressaltando que, muito embora o autor destaque que o modo pelo qual os homens produzem constitui o "momento preponderante" da conformação das relações sociais (Cf. MARX, 2011), há inúmeras imbricações relacionadas à função do Estado em meio à constituição das determinações gerais do modo de produção capitalista (assunto este tratado no livro I da obra magna do autor). Ao analisar este aspecto mais geral da obra do autor alemão, procuraremos, a partir daquilo que José Chasin chamou de análise imanente2, mostrar como que há uma correlação indissociável entre o movimento geral das figuras do processo imediato da produção capitalista e a coerção política promovida pelo Estado e regulada juridicamente.

Aqui, não seguiremos o percurso "tradicional" e "clássico" de tal análise, que passa pelo esgotamento da questão no que diz respeito à "assim chamada acumulação primitiva"; antes, tentaremos mostrar que o papel da violência estatal está presente durante todo o livro I, e não só no momento de formação da relação-capital. ${ }^{3} \mathrm{Em}$ meio a conservação diuturna desta relação social, tem-se o necessário apelo ao Estado, mesmo que isso signifique - como no caso da legislação fabril - que a esfera política possa se colocar contra os interesses imediatos da classe burguesa. Ou seja, pretendemos mostrar que "automatismo" do processo econômico, analisado por Karl Marx em O capital, passa pelo reconhecimento da peculiaridade e do papel ativo que a política exerce em diferentes momentos; procuraremos demonstrar que o processo econômico de reprodução do capital, mesmo que dê a tônica do desenvolvimento capitalista, não pode ser compreendido sem remeter à inter-relação entre o momento estatal e a conformação e

\footnotetext{
2 Como diz Chasin: "tal análise, no melhor da tradição reflexiva, encara o texto - a formação ideal - em sua consistência autosignificativa, aí compreendida toda a grade de vetores que o conformam, tanto positivos como negativos: o conjunto de suas afirmações, conexões e suficiências, como as eventuais lacunas e incongruências que o perfaçam. Configuração esta que em si é autônoma em relação aos modos pelos quais é encarada, de frente ou por vieses, iluminada ou obscurecida no movimento de produção do para-nós que é elaborado pelo investigador, já que, no extremo e por absurdo, mesmo se todo o observador fosse incapaz de entender o sentido das coisas e dos textos, os nexos ou significados destes não deixariam, por isso, de existir [...]". (CHASIN, 2009, p. 26)

${ }^{3}$ Como aponta Marx: "a relação-capital pressupõe a separação entre os trabalhadores e a propriedade das condições de realização do trabalho. Tão logo a produção capitalista se apoie sob os próprios pés, não apenas consenva tal separação, mas a reproduz em escala sempre crescente. Portanto, o processo que cria a relação-capital não pode ser outra coisa que não o processo de separação entre o trabalhador e a propriedade das suas condições de trabalho, um processo que por um lado transforma os meios sociais de subsistência e de produção em capital, por outro, os produtores imediatos em operários assalariados." (MARX, 1987, p. 252)
} 
manutenção das categorias da vida socioeconômica. Analisaremos o livro I de O capital para tratar do tema. ${ }^{4}$

\section{PolítICA E DISSOLUÇÃo dAS COMUNIDADES EM O CAPITAL}

Embora o ponto central em O capital não seja a dissolução de relações comunitárias do tipo arcaico, certamente podemos encontrar apontamentos do autor sobre a questão no livro. Ela é bastante importante para nosso tema porque, em grande parte, teve-se - em meio à influência stalinista no século XX (Cf. CLAUDIN, 2013) - a descrição marxiana da "assim chamada acumulação primitiva" como um modelo aplicável a todas as formações sociais. Isso, que fique claro, deu-se contra as palavras do próprio Marx, que, ao mesmo tempo, trata do elemento mais geral da formação do capitalismo (presente, sobretudo, em $O$ capital), mas destaca a importância da diferença específica para que se tenha uma análise efetivamente científica. (Cf. LOPES, 2012) Ao analisar o caso russo, por exemplo, o autor é explícito ao dizer sobre o capítulo XXIV de O capital:

O capítulo sobre a acumulação primitiva visa exclusivamente traçar a rota pela qual, na Europa ocidental, a ordem econômica capitalista saiu das entranhas da ordem econômica feudal. Portanto, ele acompanha o movimento que divorciou o produtor de seus meios de produção, transformando o primeiro em assalariado (proletário, no sentido moderno da palavra) e os últimos em capital. (MARX; ENGELS, 2013, p. 66).

Karl Marx é claro sobre a questão ao tratar em específico da Rússia: "restringi expressamente a 'fatalidade histórica' desse movimento aos países da Europa ocidental." (MARX, ENGELS, 2013, p. 89) Ou seja, caso se queira ser fiel ao próprio autor alemão, não há como se trazer uma generalização acrítica da "assim chamada acumulação primitiva". Ela aparece em sua via clássica no caso inglês, analisado por Marx no capítulo XXIV do livro I de O capital. No entanto, não existe somente a via clássica para o capitalismo - poderíamos falar, por exemplo, da via prussiana (Cf. LUKÁCS, 1959) e da colonial (Cf. CHASIN, 1978) - de modo que, muito embora seja possível trazer as determinações mais gerais do processo pelo qual o capitalismo se coloca sobre os próprios pés, sempre seria necessária uma visada na diferença específica colocada em cada formação social no que toca as distintas entificações do capitalismo. Marx é claro:

Quando se estuda cada uma dessas evoluções à parte, comparando-as em seguida, podese encontrar facilmente a chave desse fenômeno. Contudo, jamais se chegará a isso tendo como chave-mestra uma teoria histórico-filosófica geral, cuja virtude suprema consiste em ser supra-histórica. (MARX; ENGELS, 2013, p. 68-69)

Haveria, assim, uma chave para o fenômeno estudado, certamente. No entanto, nunca, uma "chave-mestra" ou, como em Hegel, "uma teoria histórico-filosófica geral". No limite, inclusive, pode-se dizer que o etapismo e o modelo stalinista consistiu em uma teorização "cuja virtude suprema consiste em ser supra-histórica". (Cf. CLAUDIN, 2013) Destacamos tais aspectos neste momento inicial para lançar um olhar mais cuidadoso em $O$ capital. Ao trazer à tona elementos relacionados ao processo de "acumulação

\footnotetext{
${ }^{4}$ Aqui, portanto, seguimos um caminho diferente daquele de Rosa Luxemburgo, para quem seria preciso compreender os esquemas de reprodução colocados no livro Il de O capital para que fosse possível explicar a relação entre acumulação primitiva e expansão (inclusive, política e militar) do modo de produção capitalista. (Cf. LUXEMBURGO, 1970) Também não abordamos o livro III, em que a questão aparece com bastante destaque. (Cf. SARTORI, 2019)
}

Trabalho \& Educação | v.30 | n.1 | p.11-35 | jan-abr | 2021 
primitiva", deixamos claro que ele não se dá do mesmo modo em cada formação social, tendo-se, pois, especificidades da atuação estatal em cada caso.

Levantamos também uma questão de relevo, direcionada ao papel que a política tem, segundo Marx, em momentos anteriores ao capitalismo. ${ }^{5}$ Há duas importantes passagens sobre o assunto no livro I de $O$ capital. Na primeira delas, ao tratar das "sociedades asiáticas" e das "comunidades autosuficientes", Marx traz à tona especificidades importantes:

O organismo produtivo simples dessas comunidades auto-suficientes, que se reproduzem constantemente da mesma forma e, se forem destruídas acidentalmente, são de novo reconstruídas no mesmo lugar, com o mesmo nome, oferece a chave para o segredo da imutabilidade de sociedades asiáticas que contrastam de maneira tão impressionante com a constante dissolução e reconstrução dos Estados asiáticos e com as incessantes mudanças de dinastias. A estrutura dos elementos econômicos fundamentais da sociedade não é atingida pelas tormentas desencadeadas no céu político. (MARX, 1996 a, p. 472-473)

O modo de produção asiático, com a dispersão das comunidades bem como com a centralização estatal, traria consigo uma peculiar relação entre a esfera política e o desenvolvimento - mais precisamento a imutabilidade - das sociedades asiáticas. Segundo Marx, tais comunidades, em seu isolamento, apareceriam como "autosufucientes", reproduzindo-se "constantemente da mesma forma". A questão se colocaria de tal modo que até mesmo quando são destruídas, elas "são de novo reconstruídas no mesmo lugar, com o mesmo nome". Ou seja, haveria um hiato bastante grande entre a vida comunitária e a atividade estatal do "despotismo oriental"; se é verdade que a outra face do isolamento das comunidades aldeãs seria a centralização estatal, igualmente pode-se dizer que a influência da política é diminuta no modo de produção asiático no que toca a "estrutura dos elementos econômicos fundamentais da sociedade". 6 Marx, assim, retomando a dicção de seus primeiros textos, como Crítica à filosofia de Hegel - introdução, trata do céu político.

Interessante destacar que no caso dos "Estados asiáticos", segundo Marx, mesmo com uma dinamicidade muito grande na vida política, há uma estabilidade muito grande no campo das relações econômicas fundamentais. Tal imutabilidade aparece corporificada na vida das comunas, as quais, em verdade, não são dissolvidas real e efetivamente já que, se são destruídas, "são de novo reconstruídas no mesmo lugar" - pela atividade política dos diversos Estados que se colocam sob o jugo do modo de produção asiático. A questão nos parece bastante importante: para Marx, a dissolução de modos de produção não poderia vir só das contradições presentes na vida política; em verdade, seria necessária uma mudança substantiva no próprio modo de produção social. A unidade contraditória colocada, seja no Estado nacional, seja no mercado mundial, assim, não pode derivar de imperativos "simplesmente" políticos, sendo preciso que - ao

\footnotetext{
${ }^{5}$ Não se trata simplesmente de sociedades "pré-capitalistas", mas de sociedades com especificidades importantes para a compreensão de seu ser-propriamente-assim (Geradesosein); aqui, no entanto, não poderemos tratar do assunto.

${ }^{6}$ Há de se apontar que, mesmo em O capital - portanto, em um nível bastante grande de abstração - Marx destaca que não há qualquer generalização universalizante de uma "teoria histórico-filosófica geral". Diz o autor sobre a Rússia nos Grundrisse, texto preparatório para O capital, que "o isolamento das comunidades aldeãs, a falta de laços entre suas vidas, este microcosmo localmente entrelaçado, não é sempre uma característica imanente do último dos tipos primitivos [como o russo]. Entretanto, onde quer que ocorra, permite a emergência de um despotismo central sobre as comunidades. Parece-me que na Rússia o isolamento original, causado pela grande extensão territorial, será facilmente eliminável, quando as cadeias impostas pelo governo tiverem sido rompidas." (MARX, 1985, p. 132) No caso Russo, haveria influência decisiva da atividade estatal na vida da comuna.
} 
contrário do que se dá no modo de produção asiático e no despotismo oriental - exista na regulamentação do capital e um claro papel ativo por parte do Estado para que a reprodução diuturna das relações econômicas possa se dar.

No caso das comunas arcaicas, em verdade, sua estabilidade seria decorrente de sua autonomia econômica mesma; trata-se de "comunidades auto-suficientes" em que a produção passa pelo "organismo produtivo simples". Isto se daria de tal modo que a possível (e não necessária) dissolução destas comunas ocorreria, seja pelo domínio e pela invasão estrangeira, como no caso da Índia e da China (Cf. MARX; ENGELS, 2009) ou poderia mesmo não se dar. Esta última opção aconteceria no caso Russo em que, segundo Marx, haveria, a possibilidade de a comuna "se livrar gradualmente de suas características primitivas e se desenvolver diretamente como elemento da produção coletiva em escala nacional." (MARX; ENGELS, 2013, p.89) ${ }^{7}$ Marx, portanto, destaca o caráter socialmente condicionado da influência da política em cada modo de produção e em cada formação social. Não há, em verdade, qualquer "teoria geral do Estado" no autor de $O$ capital. Marx destaca justamente a diferença específica existente no papel da política em cada formação social e em cada momento da história. No que, neste ponto de nosso texto, deve-se trazer um esclarecimento de Marx sobre seus escritos, e as críticas que os últimos receberam:

Aproveito essa oportunidade para refutar, de forma breve, uma objeção que me foi feita, quando do aparecimento de meu escrito Zur Kritik der Pol. Oekonomie,1859, por um jornal teuto-americano. Este dizia, minha opinião, que determinado sistema de produção e as relações de produção a ele correspondentes, de cada vez, em suma, "a estrutura econômica da sociedade seria a base real sobre a qual levanta-se uma superestrutura jurídica e política e à qual corresponderiam determinadas formas sociais de consciência", que "o modo de produção da vida material condicionaria o processo da vida social, política e intelectual em geral" - tudo isso estaria até mesmo certo para o mundo atual, dominado pelos interesses materiais, mas não para a Idade Média, dominada pelo catolicismo, nem para Atenas e Roma, onde dominava a política. Em primeiro lugar, é estranhável que alguém prefira supor que esses lugares-comuns arquiconhecidos sobre a Idade Média e o mundo antigo sejam ignorados por alguma pessoa. Deve ser claro que a Idade Média não podia viver do catolicismo nem o mundo antigo da política. A forma e o modo como eles ganhavam a vida explica, ao contrário, por que lá a política, aqui o catolicismo, desempenhava o papel principal. De resto basta pouco conhecimento, por exemplo, da história republicana de Roma, para saber que a história da propriedade fundiária constitui sua história secreta. Por outro lado, Dom Quixote já pagou pelo erro de presumir que a cavalaria andante seria igualmente compatível com todas as formas econômicas da sociedade. (MARX, 1996 a, p. 206).

Marx concorda, e acha mesmo óbvio, que se tenha o domínio do catolicismo na Idade Média e da política na Antiguidade. Diz mesmo que seria de uma ignorância sem tamanho não reconhecer isto. No entanto, destaca seu ponto ao deixar claro que tanto num caso como no outro, não se poderia viver doutra coisa que da relação com as "formas econômicas da sociedade". Ou seja, as trivialidades destacadas pelos seus adversários, longe de serem algo a ser tomado por base de um raciocínio científico, precisariam ser explicadas e, de acordo com o autor de $O$ capital, a explicação da questão remete à inter-relação entre as esferas política, religiosa e econômica em determinadas épocas, como a Idade Média ou a Antiguidade. A relação entre a "história

\footnotetext{
${ }^{7}$ Diz Marx sobreo tema: "se a revolução acontecer em tempo oportuno, se ela concentrar todas as suas forças para assegurar o livre crescimento da comuna rural, ela logo se desenvolverá como elemento regenerador da sociedade russa e como elemento de superioridade frente aos países submetidos ao regime capitalista." (MARX; ENGELS, 2013, p.102)
}

Trabalho \& Educação | v.30 | n.1 | p.11-35 | jan-abr | 2021 
secreta" das sociedades - que, no caso de Roma, remeteria à história da propriedade fundiária - e as formas de aparição que se apresentam de imediato na realidade efetiva precisaria ser tratada com muito cuidado.

No que diz respeito ao nosso tema, novamente, destaca-se que a política tem condicionamentos sociais e pode exercer papel mais ou menos central em determinadas épocas e sob determinadas condições. Trata-se, assim, de ter por central, não tanto uma análise que traga à política como uma esfera autônoma, mas uma explicação que traga a tona a especificidade de cada época e das condições vigentes nesta época. Somente assim seria possível uma análise cuidadosa da política. Esta última pode ser dominante em determinadas épocas e noutras não, mas nunca pode ser compreendida sem que se remeta, cuidadosamente, às "formas econômicas da sociedade".

No que toca um tema que tratamos acima - o da dissolução das comunidades - há de se notar a incapacidade da política - por si só - trazer mudanças substanciais. Nas comunas, segundo Marx, há um confronto entre formas arcaicas de produção e outras formas mais evoluídas; isto pode se dar tanto por meio do domínio estrangeiro, como no caso da China e da Índia (Cf. MARX; ENGELS, 2009), como por razões, até certo ponto, endógenas, como veio a ocorrer no caso da Rússia. (Cf. MARX; ENGELS, 2013) ${ }^{8} \mathrm{Em}$ verdade, a base real para que a política possa atuar concretamente na dissolução das comunidades arcaicas e do "organismo produtivo simples" está nas próprias relações econômicas de produção. No livro I de O capital, Marx trata de trazer o efeito da tendencial universalização da troca de mercadorias sobre as distintas formas de comunidades:

O primeiro modo, pelo qual um objeto de uso é possivelmente valor de troca, é sua existência como não-valor de uso, como quantum de valor de uso que ultrapassa as necessidades diretas de seu possuidor. As coisas são, em si e para si, externas ao homem e, portanto, alienáveis. Para que a alienação seja recíproca, basta que os homens se defrontem, tacitamente, como proprietários privados daquelas coisas alienáveis e portanto, por intermédio disso, como pessoas independentes entre si. Tal relação de estranhamento recíproco não existe, porém, para os membros de uma comunidade primitiva, tenha ela a forma de uma família patriarcal, de uma antiga comunidade indiana, um Estado inca etc. A troca de mercadorias começa onde as comunidades terminam, em seus pontos de contato com outras comunidades ou com membros de outras comunidades. Tão logo as coisas se tornam mercadorias no exterior da comunidade, tornam-se também por repercussão mercadorias no interior da vida comunal. Sua relação quantitativa de troca é por enquanto inteiramente casual. São permutáveis pela vontade de seus possuidores de aliená-las reciprocamente. (MARX, 1996 a, p. 212).

A "comunidade primitiva, tenha ela a forma de uma família patriarcal, de uma antiga comunidade indiana, um Estado inca, etc." não tem como característica que seus membros sejam essencialmente proprietários privados. Para que um valor de uso apareça como valor de troca, assim, é necessário tanto que se tenha uma produção que ultrapassa a necessidade imediata quanto que as relações sociais não se concatenem de modo arcaico. A troca de mercadorias aparece "de fora" das comunidades relacionadas ao "modo de produção asiático"; o excedente só pode aparecer como mercadoria porque já há contato com sociedades que trazem em seu bojo a lógica mercantil, mesmo que esta não apareça, em todos os casos, como central. Assim, primeiramente, "as coisas se tomam mercadorias no exterior da comunidade" para que, somente então, elas possam se tomar "também por repercussão das mercadorias no

\footnotetext{
8 Para uma análise cuidadosa deste processo, Cf. LENIN, 1982.
} 
interior da vida comunal". Assim, o processo de dissolução das comunidades arcaicas passa necessariamente por um elemento "extemo": seja de modo mais gradual, com a introdução da lógica mercantil, seja com o elemento diretamente político-militar da invasão estrangeira, ligada ao colonialismo. (Cf. MARX, 1996 b) Deve-se destacar, porém: enquanto a "relação quantitativa de troca é [...] inteiramente casual", não se tem real e efetivamente a dissolução da comunidade arcaica. E, neste sentido, a política não consegue, também neste caso, ter uma influência decisiva, como teve em Roma ou na Grécia, ou mesmo na moderna sociedade civil-burguesa. E mais, somente depois que é superada a situação em que os produtos "são permutáveis pela vontade de seus possuidores de aliená-las reciprocamente" sem que se tenha a imposição dos imperativos produtivos do capital é que a dissolução das comunidades está completa e estas são historicamente anacrônicas.

Ou seja, a partir de uma leitura cuidadosa do livro I de O capital, é preciso que se perceba a determinação social da política, bem como a sua dependência diante de condições que derivam, essencialmente, das condições de produção. Os meandros da questão são muitos, de modo que tanto a especificidade de cada época quanto o papel que a política pode cumprir em cada momento da história devem ser destacados. Pelo que vimos, portanto, pode-se afirmar que, por mais que a politica tenha um papel ativo na conformação da vida social, a potência presente nesta intervenção estatal pode variar profundamente. Isto, claro, não pode ser reduzido às relações sociais de produção de uma época, mas depende, em sua essência, de condições gestadas na produção.

\section{ACUMULAÇÃO PRIMITIVA, RELAÇÃO-CAPITAL COLOCADA SOBRE OS PRÓPRIOS PÉS E VIOLÊNCIA ESTATAL COMO POTÊNCIA ECONÔMICA}

Por mais que o centro de nosso artigo não seja a acumulação primitiva, ela precisa aparecer. Isso se dá, primeiramente, de modo negativo: para que mostremos que o processo que ocorreu na Inglaterra, segundo Marx, não pode ser tomado acriticamente como modelo. Deve-se destacar, porém, outro aspecto, por assim dizer, "positivo" da questão: a "assim chamada acumulação primitiva" não pode ser reduzida ao processo de separação entre trabalhadores e meios de produção. Há tanto elementos relacionados à "superpopulação relativa" quanto à regulação dos salários que precisam ser vistos neste meandro. E mais: o papel ativo do Estado no que toca o endividamento não pode ser esquecido. Tais aspectos foram pouco destacados ao tratar do livro I de $O$ capital.

Harvey propôs uma leitura que traz estes elementos para a atualidade no que ele chama de "acumulação por despossessão" (Cf. HARVEY, 2011, 2005); no entanto, na análise imanente da obra de Marx sobre este ponto, o autor vem a trazer muito pouco sobre nosso tema. (Cf. HARVEY, 2013) Deste modo, procuraremos trazer a questão da política à tona ao tratar de algumas passagens decisivas da obra magna de Marx e que dizem respeito a elementos geralmente negligenciados do processo da "assim chamada acumulação primitiva". Um dos traços importantes a ser levado em conta diz respeito à relação entre o Estado, a migração e a superpopulação relativa. Diz Marx:

Em consequência da guerra civil americana e da crise do algodão que a acompanhou, como se sabe, a maioria dos trabalhadores algodoeiros em Lancashire foi jogada na rua. Do seio da própria classe trabalhadora, como de outras camadas da sociedade, ergueu-se um clamor pelo apoio do Estado ou por uma coleta nacional voluntária, a fim de possibilitar a 
emigração dos "supérfluos" para as colônias inglesas ou para os Estados Unidos. (MARX,1996 b, p. 207)

A questão da superpopulação relativa, longe de trazer um elemento naturalista, como em Malthus, remete ao meandrado desenvolvimento do capital. (Cf. MARX, 1980) Os trabalhadores se tornam "supérfluos" somente do ponto de vista do modo de produção capitalista, e não "em absoluto". Isto se dá até mesmo quando se tem, em um primeiro momento, o surgimento do lumpem proletariado e de "mendigos, assaltantes, vagabundos" que "expulsos pela dissolução dos séquitos feudais e pela expropriação violenta e intermitente de suas terras", conformavam "esse proletariado inteiramente livre não podia ser absorvido pela manufatura emergente com a mesma rapidez com que fora trazido ao mundo." (MARX, 2013, p. 980) ${ }^{9}$ Trata-se do processo que se liga tanto ao surgimento das "workhouses", quanto do cárcere moderno. (Cf. MELOSSI; PAVARINI, 2004 e RUSCHE; KIRCHEIMER, 2006) Dado que os trabalhadores não podiam ser absorvidos de imediado pela indústria nascente, a sociedade capitalista nasce sob a sombra da superpopulação relativa. Esta última, assim, acompanha tanto o processo de "acumulação primitiva" quanto o processo de desenvolvimento social das diversas formações sociais capitalistas, formações estas que podem se relacionar com o colonialismo moderno de um modo mais ou menos meandrado.

Esta questão, assim, não faz parte só de um momento inicial do capitalismo. Em meio às crises e às contingências da produção capitalista, grandes quantidades de trabalhadores são jogados na rua. E, deste modo, tal como no processo de acumulação primitiva se oscilava entre a caridade e soluções mais violentas, aqui se tem o mesmo. ${ }^{10}$ Marx havia dito em 1848 que se tratava, em verdade, de uma "caridade feroz" (MARX, 2010 a, p. 369) ${ }^{11}$, que demonstrava a verdadeira natureza da sociedade capitalista.

\footnotetext{
${ }^{9}$ Veja-se a passagem inteira de Marx: "expulsos pela dissolução dos séquitos feudais e pela expropriação violenta e intermitente de suas terras, esse proletariado inteiramente livre não podia ser absorvido pela manufatura emergente com a mesma rapidez com que fora trazido ao mundo. Por outro lado, os que foram repentinamente arrancados de seu modo de vida costumeiro tampouco conseguiam se ajustar à disciplina da nova situação. Converteram-se massivamente em mendigos, assaltantes, vagabundos, em parte por predisposição, mas na maioria dos casos por força das circunstâncias. Isso explica o surgimento, em toda a Europa ocidental, no final do século XV e ao longo do século XVI, de uma legislação sanguinária contra a vagabundagem. Os pais da atual classe trabalhadora foram inicialmente castigados por sua metamorfose, que lhes fora imposta, em vagabundos e paupers. A legislação os tratava como delinquentes 'voluntários' e supunha depender de sua boa vontade que eles continuassem a trabalhar sob as velhas condições, já inexistentes." (MARX, 2013, p. 980)

${ }^{10}$ A questão já havia aparecido em 1844 nas chamadas Glossas marginais, em que diz Marx: "o pauperismo é a miséria da qual os próprios trabalhadores são culpados e ao qual portanto não se deve prevenir como uma desgraça, mas antes reprimir e punir como um delito. [...] Nas workhouses, a assistência é engenhosamente entrelaçada com a vingança da burguesia contra o pobre que apela à sua caridade." (MARX, 2010 b, p. 53)

11 Veja-se a passagem completa em que Marx trata desta relação: "na Inglaterra, onde a dominação da burguesia é a mais desenvolvida, a caridade pública também assumiu, como se sabe, as formas mais nobres e magnânimas. As workhouses inglesas - estabelecimentos públicos em que a população trabalhadora excedente vegeta às custas da sociedade burguesa - aliam de maneira verdadeiramente refinada a caridade à vingança que a burguesia descarrega nos miseráveis coagidos a apelar à sua caridade. Os pobres diabos não apenas são alimentados com os meios de subsistência mais parcos, miseráveis e que mal são suficientes para a reprodução física, como também sua atividade é limitada a uma simulação de trabalho improdutiva, repugnante, embotadora do espírito e do corpo - por exemplo, mover moinhos a pedal. Para tornar perfeitamente claro aos infelizes toda a grandeza de seu crime, um crime que consiste em, no lugar de ser material produtivo e lucrativo para a burguesia, como no curso normal da vida, ter se transformado antes em custo para seu usufrutuário nato, do mesmo modo que os tonéis de bebidas deixados no depósito se tornam custo para o comerciante de álcool; para que aprendam a perceber toda a grandeza desse crime, são privados de tudo o que se concede aos criminosos comuns, convívio com mulher e filhos, entretenimento, fala - tudo. E mesmo essa 'caridade feroz' da burguesia inglesa não se baseia de modo algum em razões apaixonadas, mas sim muito práticas, inteiramente calculáveis. De um lado, a ordem burguesa e a atividade comercial poderiam sofrer de maneira inquietante se todos os paupers da Grã-Bretanha fossem subitamente arre messados à rua. Por outro lado, a indústria inglesa oscila entre períodos de febril superprodução, em que a demanda por braços mal pode ser atendida e os braços devem ser obtidos
}

Trabalho \& Educação | v.30 | n.1 | p.11-35 | jan-abr | 2021 
Depois do momento que o capitalismo se coloca sobre os próprios pés, ou seja, após a consolidação da acumulação primitiva, as crises deixam trabalhadores desempregados de modo que estes clamam por intervenção estatal para que possam, por exemplo, ser levados a colônias (no caso tratado por Marx, inglesas). Um dos modos de lidar com a superpopulação relativa, portanto, é a imigração, que é realizada com intervenção estatal em meio ao moderno colonialismo. Outros dois modos são: caridade e as workhouses, essenciais na formação dos trabalhadores modernos. Diz Marx sobre elas e a sua relação com o trabalho infantil:

\begin{abstract}
$\mathrm{Na}$ Inglaterra, ainda ocorre que mulheres peguem crianças da Workhouse e as aluguem para qualquer comprador por 2 xelins e 6 pence por semana. Apesar da legislação, pelo menos 2 mil jovens continuam sendo vendidos por seus próprios pais como máquinas vivas para limpar chaminés (apesar de existirem máquinas para substituí-los). A revolução acarretada pela maquinaria na relação jurídica entre comprador e vendedor de força de trabalho, de maneira que a transação toda perde até mesmo a aparência de um contrato entre duas pessoas livres, propiciou mais tarde ao Parlamento inglês a escusa jurídica para a ingerência do Estado no sistema fabril. (MARX, 1996 b, p. 30).
\end{abstract}

Diante das situações desumanas da emergência do sistema fabril, os pais vendiam sua prole para realizar trabalhos que poderiam facilmente ser realizados por máquinas, mas que, diante do menor custo, eram realizados por crianças. Tratava-se da época em que "o capital celebrava suas orgias". (MARX, 1996 a, p. 391) Segundo Marx, "ocorreu então, a partir do nascimento da grande indústria no último terço do século XVIII, um assalto desmedido e violento como uma avalancha." No que continua o autor: "toda barreira interposta pela moral e pela natureza, pela idade ou pelo sexo, pelo dia e pela noite foi destruída." (MARX, 1996 a, p. 391) Logo após o processo de acumulação primitiva, buscou-se a espoliação máxima dos trabalhadores, tendo-se a implementação, pela violência, também estatal, de longas jornadas de trabalho e de condições aviltantes de trabalho. Deixado livre, o sistema fabril aparecia como algo que consumia trabalhadores de modo predatório. A implementação da maquinaria, em um primeiro momento, levou não só ao aumento da produtividade, mas à destruição das capacidades individuais e produtivas dos indivíduos trabalhadores. A situação seria tal que a própria transação jurídica voluntária "perde até mesmo a aparência de um contrato entre duas pessoas livres". A política, assim, torna-se uma potência econômica na medida em que propicia as condições para que o sistema fabril seja violentamente imposto. A base real do processo, claro, está nas possibilidades presentes na própria faticidade da efetividade econômica, mas há mediações importantes:

Não basta que as condições de trabalho apareçam num polo como capital e no outro polo, pessoas que nada têm para vender a não ser sua força de trabalho. Não basta também forçarem-nas a se venderem voluntariamente. $\mathrm{Na}$ evolução da produção capitalista, desenvolve-se uma classe de trabalhadores que, por educação, tradição, costume, reconhece as exigências daquele modo de produção como leis naturais evidentes. (MARX, 1996 b, p. 358).

O processo mediante o qual os indivíduos se tomam proletários é aquele de imposição das condições de trabalho do sistema capitalista. Assim, não basta que os indivíduos

tão barato quanto possível, e períodos de recuo comercial, em que a produção excede largamente o consumo e apenas com esforço a metade do exército de trabalhadores pode ser empregada, com metade do salário. Que meio mais sensato do que as workhouses para manter à disposição um exército de reserva para os períodos favoráveis e, ao mesmo tempo, durante os períodos desfavoráveis para o comércio, transformá-lo, pela punição nestes piedosos estabelecimentos, em máquina sem vontade, sem resistência, sem exigências, sem necessidades?"(MARX, 2010 a, p. 369) 
precisem vender sua força de trabalho para que o façam. Como já mencionado, eles têm, até certo ponto, alternativas: podem, por exemplo, tornar-se "mendigos, assaltantes, vagabundos". E, não se pode deixar de destacar: mesmo que não se trate de algo revolucionário - e, verdade, segundo Marx, tais camadas tendem à reação - ${ }^{12}$, tem-se aí uma resistência à imposição do modo de produção capitalista. Ou seja, destaca Marx: há resistências tanto na implementação quanto na manutenção do modo de produção capitalista. E, neste sentido, é bastante necessário à reprodução diutuma do capital formar "uma classe de trabalhadores que, por educação, tradição, costume, reconhece as exigências daquele modo de produção como leis naturais evidentes." Neste processo, a atuação estatal é central, seja ela direta, seja por meio das workhouses, ou por meio do cárcere, a questão é de bastante relevo. No entanto, há de se perceber que também as escolas (aquilo que Marx depois veio a chamar de educação popular inclusive) têm um papel bastante importante, juntamente com o costume.

Ou seja, para que se tenha as leis da produção capitalista como uma espécie de segunda natureza, o processo de imposição política da burguesia precisa estar adiantado. A política, portanto, tem um papel ativo bastante grande em meio ao desenvolvimento da moderna sociedade civil-burguesa; no limite, como dito, por métodos nada idílicos, coloca-se como uma "potência econômica". O Estado atua "regulando a produção", em um primeiro momento, justamente para que as orgias do capital fossem "naturais" e "necessárias". Na transição ao capitalismo isto é patente:

Esses métodos baseiam-se, em parte, sobre a mais brutal violência, por exemplo, o sistema colonial. Todos, porém, utilizaram o poder do Estado, a violência concentrada e organizada da sociedade, para ativar artificialmente o processo de transformação do modo feudal de produção em capitalista e para abreviar a transição. A violência é a parteira de toda velha sociedade que está prenhe de uma nova. Ela mesma é uma potência econômica. (MARX,1996 b, p. 370).

Alguns aspectos da ligação entre o sistema colonial, a superpopulação relativa e o modo de produção capitalista já foram explicitados acima. Há de se destacar, assim, que a inter-relação entre a esfera econômica e o Estado - ou seja, a "violência concentrada e organizada da sociedade" - traz consigo uma natureza peculiar. Mesmo nos momentos em que o Estado tem o papel mais ativo, ele tem uma subordinação patente diante do desenvolvimento das relações materiais de produção; aquele momento em que ele tem maior potência - quando é "a parteira de toda a velha sociedade que está prenhe de uma nova" - é aquele em que há uma correção, pode-se dizer, mais íntima entre a economia e a política. Neste ponto, a violência estatal se conforma de tal modo que "ela mesma é uma potência econômica". Ou seja, mesmo antes de um modo de produção se colocar sobre seus próprios pés, a função do Estado é bastante limitada: ele colocase subordinado às possibilidades presentes em meio à concatenação real e efetiva das relações sociais de produção. ${ }^{13}$ A relação-capital, assim, coloca-se sobre os próprios pés somente ao passo que a violência estatal é bastante utilizada; no entanto, ela, por si só, não basta, sendo preciso tanto condições materiais quanto o desenvolvimento conjunto da formação e conformação das individualidades: tem-se, com isso, o processo mediante o qual "desenvolve-se uma classe de trabalhadores que, por educação,

\footnotetext{
12 Marx e Engels apontam no Manifesto comunista que o lumpem é "putrefação passiva das camadas mais baixas da velha sociedade, [que] pode, às vezes, ser arrastado ao movimento por uma revolução proletária; [mas que], todavia, suas condições de vida o predispõem mais a vender-se à reação". (MARX; ENGELS, 1998, p. 49).

${ }^{13}$ Para um tratamento cuidadoso da questão, Cf. LUKÁCS, 2012 e CHASIN, 2009.
} 
tradição, costume, reconhece as exigências daquele modo de produção como leis naturais evidentes". Somente então o uso da violência - ela mesma uma "potência econômica" - cede espaço para o desenvolvimento "automático" das relações econômicas. Pelo que vimos aqui, porém, este "automatismo", mesmo que tenha como momento preponderante o próprio fator econômico, precisa da intervenção jurídicoestatal para que seja reproduzido diuturnamente. (Cf. LUKÁCS, 2012)

Tanto na acumulação primitiva quanto depois que a relação-capital é colocada sobre os próprios pés tem-se a imprescindibilidade do Estado. Marx, acima, mencionou a "revolução acarretada pela maquinaria", por exemplo. Por meio dela, tem-se tanto uma mudança substantiva nas relações sociais de produção quanto mudanças políticojurídicas. O processo capitalista de produção se imporia de tal modo que tem-se a "relação jurídica entre comprador e vendedor da força de trabalho" entificando-se de modo diferenciado: "a transação perde até mesmo a aparência de um contrato livre entre duas pessoas". A questão deve ser destacada porque tamanho grau de exploração da força de trabalho somente é possível em circunstâncias específicas, colocadas "depois que o capital precisou de séculos para prolongar a jornada de trabalho até seu limite máximo normal e para ultrapassá-lo até os limites do dia natural de 12 horas". (MARX, 1996 a, 391) Neste momento, o papel ativo do Estado era tal que a "potência econômica" explicitava-se na medida em que "os próprios conceitos de dia e noite, rusticamente simples nos velhos estatutos, confundiram-se tanto que um juiz inglês, ainda em 1860, teve de empregar argúcia verdadeiramente talmúdica, para esclarecer 'juridicamente' o que seja dia e o que seja noite." (MARX, 1996 a, 391)

\section{O GRAU NORMAL DE DEPENDÊNCIA DO TRABALHADOR E A REGULAMENTAÇÃO JURÍDICA DA ATIVIDADE FABRIL}

A regulamentação jurídica da atividade fabril tem uma dupla face. De um lado, aparece como uma necessidade do próprio capital. Isso se dá porque, por mais elásticos que sejam os limites da jornada de trabalho, em algum momento, é necessário que a competição capitalista tenha por base ganhos de produtividade. (Cf. MARX, 1996 a, b) $\mathrm{Na}$ "assim chamada acumulação primitiva", com ferro e fogo, consegue-se alcançar principalmente pela imposição do próprio processo econômico, mas também pela educação, pela tradição e pelo costume - o "grau normal de dependência do trabalhador". Marx é explícito ao dizer que "a burguesia nascente precisa e emprega a força do Estado para 'regular' o salário, isto é, para comprimi-lo dentro dos limites convenientes à extração de mais-valia, para prolongar a jornada de trabalho e manter o próprio trabalhador num grau normal de dependência." Diz o autor que "esse é um momento essencial da assim chamada acumulação primitiva." (MARX, 1996 b, p. 359) Ou seja, a acumulação primitiva coloca o capitalismo sobre os próprios pés e traz tanto o "grau normal de dependência do trabalhador" quanto "uma classe de trabalhadores que, por educação, tradição, costume, reconhece as exigências daquele modo de produção como leis naturais evidentes." A política, no capitalismo, assim, parece ter uma função essencial, e tem. No entanto, devemos lembrar que isto se dá ao passo que ela mesma é uma "potência econômica" de tal modo que o solo em que ela consegue se impor é aquele das relações sociais de produção, solo este marcado pelo desenvolvimento das contradições capitalistas. Marx, ao tratar da "jornada normal de trabalho", diz algo de grande relevo: 
A criação de uma jornada normal de trabalho é, por isso, o produto de uma guerra civil de longa duração, mais ou menos oculta entre a classe capitalista e a classe trabalhadora. Como a luta foi inaugurada no âmbito da indústria mais moderna, travou-se primeiro na terra natal dessa indústria, na Inglaterra. (MARX, 1996 a, p. 411).

A regulamentação da jornada de trabalho, e da atividade fabril, é, ao mesmo tempo, uma necessidade da reprodução capitalista e uma conquista da classe trabalhadora. ${ }^{14} \mathrm{~A}$ natureza da questão remete a certa dubiedade, portanto. Se, em um primeiro momento, os trabalhadores são forçados a "se venderem voluntariamente", após a mudança levada a cabo pela maquinaria - que envolve a própria relação entre a livre vontade e o contrato jurídico - tem-se que "logo que a classe trabalhadora, atordoada pelo barulho da produção, recobrou de algum modo seus sentidos, começou sua resistência, primeiro na terra natal da grande indústria, na Inglaterra." (MARX, 1996 a, p. 391) Ou seja, tão logo o capital celebra "suas orgias", vem a luta da classe trabalhadora. A dubiedade da questão aparece ao passo que se tem "concessões conquistadas por ela". (MARX, 1996 a, p. 391) Correlato ao momento em que a classe trabalhadora é formada em um processo em que é obrigada a vender a voluntariamente a si mesma e a sua prole, temse o momento em que a resistência desta classe traz conquistas. Trata-se de conquistas dentro do próprio assalariamento e, assim, em verdade, tem-se "concessões conquistadas" e que, por muito tempo - em meio à guerra civil que conforma a luta de classes - "permaneceram letra morta". (MARX, 1996 a, p. 391 Assim, a conquista da classe trabalhadora é bastante dúbia: até certo ponto, supõe o modo de produção capitalista e se volta contra a própria vontade imediata dos indivíduos que compõem esta classe e são forçados a vender a si mesmos e a sua prole ao capital. Diz Marx: "como 'proteção' contra a serpente de seus martírios, os trabalhadores têm de reunir suas cabeças e como classe conquistar uma lei estatal, uma barreira social intransponível, que os impeça a si mesmos de venderem a si e à sua descendência, por meio de contrato voluntário com o capital, à noite e à escravidão!" (MARX, 1996 a, p. 414) O estabelecimento da jornada normal de trabalho, que é trazido pela "escusa jurídica para a ingerência do Estado no sistema fabril" é tanto o resultado das contradições da própria reprodução do capital quanto o fruto das lutas dos trabalhadores em meio à imposição dos imperativos da produção capitalista. No que se diz em O capital algo bastante importante sobre a relação entre mais-valor relativo, mais-valor absoluto e desenvolvimento do modo de produção:

$\mathrm{Na}$ Inglaterra o prolongamento da jornada de trabalho avançou durante meio século paralelamente com a crescente intensificação do trabalho na fábrica. No entanto torna-se compreensível que, num trabalho que não se caracteriza por paroxismos transitórios, mas por uma uniformidade regular, repetida a cada dia, tem que se alcançar um ponto nodal em que prolongamento da jornada de trabalho e intensidade do trabalho excluem-se mutuamente, de modo que o prolongamento da jornada de trabalho só é compatível com um grau mais fraco de intensidade do trabalho e, vice-versa, um grau mais elevado de intensidade com a redução da jornada de trabalho. Assim que a revolta cada vez maior da classe operária obrigou o Estado a reduzir à força a jornada de trabalho e a ditar, inicialmente às fábricas propriamente ditas, uma jornada normal de trabalho, a partir desse instante, portanto, em que se impossibilitou de uma vez por todas a produção crescente de mais-valia

\footnotetext{
${ }^{14}$ Aqui não podemos tratar da questão com cuidado, mas, ao que nos parece, o tratamento da questão por Edelman, por vezes, tende a unilateralidade. Isto se dá, sobretudo, na Legalização da classe operária. (2016) Em sua obra anterior, principalmente em O Direito captado pela fotografia (1976) a questão aparece de modo mais condizente com o elemento dúplice presente na obra do próprio Marx.
} 
mediante o prolongamento da jornada de trabalho, o capital lançou-se com força total e plena consciência à produção de mais-valia relativa por meio do desenvolvimento acelerado do sistema de máquinas. Ao mesmo tempo, ocorreu uma modificação no caráter da mais-valia relativa. Em geral, o método de produção da mais-valia relativa consiste em capacitar o trabalhador, mediante maior força produtiva do trabalho, a produzir mais com o mesmo dispêndio de trabalho no mesmo tempo. O mesmo tempo de trabalho continua a adicionar o mesmo valor ao produto global, embora esse valor de troca inalterado se apresente agora em mais valores de uso e, por isso, caia o valor da mercadoria individual. Outra coisa, porém, ocorre assim que a redução forçada da jornada de trabalho, com o prodigioso impulso que ela dá ao desenvolvimento da força produtiva e à economia das condições de produção, impõe maior dispêndio de trabalho, no mesmo tempo, tensão mais elevada da força de trabalho, preenchimento mais denso dos poros da jornada de trabalho, isto é, impõe ao trabalhador uma condensação do trabalho a um grau que só é atingível dentro da jornada de trabalho mais curta. Essa compressão de maior massa de trabalho em dado período de tempo conta, agora, pelo que ela é: como maior quantum de trabalho. Ao lado da medida do tempo de trabalho como "grandeza extensiva", surge agora a medida de seu grau de condensação. Mas influência no tempo de trabalho como medida de valor só ocorre também aqui enquanto a grandeza intensiva e a extensiva se colocam como expressões antitéticas e mutuamente excludentes do mesmo quantum de trabalho. (MARX, 1996 b, p. 42-43).

O aumento do tempo de trabalho deu a tônica do momento inicial do modo de produção capitalista. ${ }^{15}$ No entanto, tal tendência - que leva a uma relação predatória com a classe trabalhadora - não poderia se prolongar indefinidamente com o próprio desenvolvimento de tal sistema produtivo, em que o aumento da produtividade do trabalho é importante em um duplo sentido: de um lado, para que seja possível trazer vantagens no campo da própria concorrência; doutro, tem-se a resposta à revolta da classe trabalhadora. A "jornada normal de trabalho", vem, assim, a se caracterizar, em meio às contradições da produção, por meio da imposição, por parte do Estado, de uma regulamentação fabril. Tem-se tanto a "escusa jurídica para a ingerência do Estado no sistema fabril" quanto a conquista de uma concessão por parte do proletariado moderno. Diz Marx que "a revolta cada vez maior da classe operária obrigou o Estado a reduzir à força a jomada de trabalho e a ditar, inicialmente às fábricas propriamente ditas, uma jornada normal de trabalho". Para lidar com uma situação em que "o prolongamento da jornada de trabalho e a intensidade do trabalho excluem-se mutuamente", portanto, há de se voltar ao incremento da produtividade do trabalho, tendo-se a intervenção estatal como um momento essencial, embora subordinado ao desenvolvimento da produção. Tal regulamentação advém do reconhecimento da luta dos trabalhadores. Mas também traz um impulso ao sistema capitalista, que passa a investir em capital constante: "o capital lançou-se com força total e plena consciência à produção de mais-valia relativa por meio do desenvolvimento acelerado do sistema de máquinas." Ou seja, o Estado, por mais

\footnotetext{
${ }^{15}$ Como diz Marx: "o estabelecimento de uma jornada normal de trabalho é o resultado de uma luta multissecular entre capitalista e trabalhador. Entretanto, a história dessa luta mostra duas tendências opostas. Compare-se, por exemplo, a legislação fabril inglesa de nosso tempo com os estatutos ingleses do trabalho do século XIV até bem na metade do século XVIII. Enquanto a moderna lei fabril reduz compulsoriamente a jornada de trabalho, aqueles estatutos procuravam compulsoriamente prolongá-la. Sem dúvida, as pretensões do capital, em seu estado embrionário, quando ele ainda virá a ser, portanto, em que ainda não assegura mediante a simples força das condições econômicas, mas também mediante a ajuda do poder do Estado, seu direito de absorver um quantum suficiente de mais-trabalho parecem até modestas, se as compararmos com as concessões que ele tem de fazer rosnando e resistindo, em sua idade adulta. Custou séculos para que o trabalhador "livre", como resultado do modo de produção capitalista desenvolvido, consentisse voluntariamente, isto é, socialmente coagido, em vender todo o seu tempo ativo de sua vida, até sua própria capacidade de trabalho, pelo preço de seus meios de subsistência habituais, e seu direito à primogenitura por um prato de lentilhas. É natural, portanto, que a prolongação da jornada de trabalho, que o capital procura impor aos trabalhadores adultos por meio da força do Estado, da metade do século XIV ao fim do século XVII, coincida aproximadamente com a limitação do tempo de trabalho que, na segunda metade do século XIX, é imposta pelo Estado, aqui e acolá, à transformação de sangue infantil em capital." (MARX, 1996 a, p. 384)
}

Trabalho \& Educação | v.30 | n.1 | p.11-35 | jan-abr | 2021 
que se coloque - no caso da regulamentação da atividade fabril - contra a vontade individual dos capitalistas, é necessário ao desenvolvimento das potencialidades do próprio sistema capitalista.

A extração do mais-valor relativo implica no investimento na formação da própria classe trabalhadora, de modo que esta última deixa de ser tratada - ao menos nos momentos em que prepondera a busca por incremento no mais-valor relativo e não no absoluto como algo imediatamente substituível e que pode ser extenuado e espoliado de modo predatório. ${ }^{16}$ Diz Marx, neste sentido, que "o método de produção da mais-valia relativa consiste em capacitar o trabalhador, mediante maior força produtiva do trabalho, a produzir mais com o mesmo dispêndio de trabalho no mesmo tempo." Assim, a intervenção estatal tem um papel bastante grande para que seja possível o desenvolvimento da produtividade do trabalho; nisso, inclusive, o investimento estatal em educação é essencial. ${ }^{17}$ A divisão capitalista do trabalho, assim, passa a implicar na qualificação de uma camada de trabalhadores que realiza o trabalho de supervisão, bem como o trabalho comercial, que precisam de uma educação mais sólida. ${ }^{18}$ Marx diz sobre a questão que "a generalização do ensino popular permite recrutar essa espécieentre classes que antes estavam excluídas, acostumadas a um modo de vida pior. Ademais ela aumenta o afluxo e, com isso, a concorrência." (MARX, 1986, p. 225-226) Ou seja, o papel ativo do Estado, ao se ter em conta a extração de mais-valor relativo, passa tanto pelo desenvolvimento do "ensino popular" quanto por meio da regulamentação da atividade fabril. A atuação política, assim, mesmo que resulte da conquista de concessões por parte da classe trabalhadora, tem como base real o movimento do próprio capital. Diz Marx que "essas leis refreiam o impulso do capital por sucção desmesurada da força de trabalho, por meio da limitação coercitiva da jornada de trabalho pelo Estado e na verdade por um Estado que capitalista e Landlord dominam." (MARX, 1996 a, p. 353)

Deve-se dizer, portanto, que o solo sobre o qual se coloca a conquista de direitos no campo do trabalho e da educação é aquele da extração do mais-valor relativo; assim, há de se pensar que, se, eventualmente, tem-se uma derrota histórica da classe trabalhadora, ou a queda da taxa de lucro colocada de tal modo que deve-se - do ponto de vista capitalista - buscar a extração do mais-valor absoluto, há uma chance bastante grande da perda destes direitos, colocada na ofensiva do capital.

\footnotetext{
${ }^{16}$ Neste processo, é importante também algum cuidado com a alimentação dos trabalhadores, bem como com as condições de trabalho, não só nas esferas ligadas à atividade fabril. No que, diz Marx sobre o trabalho dos padeiros: "o inglês apegado à Bíblia sabia que o ser humano, quando graças à Divina Providência não se torna capitalista ou landlord ou sinecurista, está condenado a comer pão com o suor de seu rosto; mas ele não sabia que tinha de comer com seu pão diário certo quantum de suor humano, embebido com supurações de abcessos, teia de aranha, baratas mortas e fermento podre alemão, além de alúmen, arenito e outros agradáveis ingredientes minerais. Sem nenhuma consideração pela sua santidade, o freetrade, a panificação, até então 'livre', foi submetida à fiscalização de inspetores do Estado (final da legislatura de 1863), e pelo mesmo ato do Parlamento foi proibido o horário de trabalho das 9 horas da noite até as 5 da manhã aos oficiais de padeiros menores de 18 anos. A última cláusula vale por volumes inteiros no que se refere ao excesso de trabalho nesse ramo de negócio para nós tão paternalmente caseiro." (MARX, 1996 a, p. 363-364)

17 Tem-se na relação entre educação e valor da força de trabalho: "na comparação de salários nacionais devem ser pois considerados todos os momentos determinantes da variação na grandeza de valor da força de trabalho, preço e volume das primeiras necessidades vitais naturais e historicamente desenvolvidas, custos da educação do trabalhador, papel do trabalho feminino e infantil, produtividade do trabalho, sua grandeza extensiva e intensiva." (MARX, 1996 b, p. 189)
}

18Diz Marx: "a fim de evitar a degeneração completa da massa do povo, originada pela divisão do trabalho, A. Smith recomenda o ensino popular pelo Estado, embora em doses prudentemente homeopáticas." (MARX, 1996 a, p. 476) 
Para Marx, portanto, deve-se ser claro: as conquistas históricas da classe trabalhadora, enquanto há capitalismo, não estão nem podem estar a salvo de uma ofensiva do capital.

O incremento do mais-valor relativo, implica em uma intensificação do trabalho na medida em que este se torna mais qualificado e em que necessita de maior tempo para a formação completa da mercadoria força de trabalho. Diz Marx que este processo "impõe maior dispêndio de trabalho, no mesmo tempo, tensão mais elevada da força de trabalho, preenchimento mais denso dos poros da jornada de trabalho, isto é, impõe ao trabalhador uma condensação do trabalho a um grau que só é atingível dentro da jornada de trabalho mais curta." Deve-se, novamente, destacar a dubiedade da questão: por meio da política e do Direito, ao mesmo tempo, reconhece-se as lutas dos trabalhadores e os imperativos da reprodução capitalista. A força de trabalho, no que toca a formação de seu valor, aparece tendo como medida o tempo socialmente necessário, certamente. Mas isto se dá de tal modo que se deve ter em conta também "seu grau de condensação".

Se o que diz Marx é verdadeiro, o momento em que se tem incremento de direitos é aquele em que se tem luta de classes, e vitórias parciais da classe trabalhadora. Mas isto também está relacionado ao desenvolvimento da extração de mais-valor relativo, em que "a grandeza intensiva e a extensiva se colocam como expressões antitéticas e mutuamente excludentes do mesmo quantum de trabalho." Ou seja, o solo sobre o qual se coloca a intervenção estatal e a regulamentação jurídica - e, portanto, as conquistas jurídicas - é aquele da produção capitalista e de suas contradições. Estas últimas, mesmo que possam ser atenuadas com o Estado e o Direito, não podem ser suspensas. Assim, segundo Marx, as possibilidades que vêm com o papel ativo da política são bastante dependentes do grau de desenvolvimento e dos antagonismos do sistema capitalista.

O processo dúplice que dá ensejo à "jornada normal de trabalho" é aquele em que, ao mesmo tempo, os imperativos do capital desenvolvem-se e que a classe trabalhadora consegue vitórias parciais. No que se deve dizer algo muito importante sobre este aspecto: de acordo com Marx, não é possível ter ilusões quanto a este processo em 2 sentidos antagônicos. Em um primeiro deles, é preciso que se note que, se não fosse pela luta dos trabalhadores, tais ganhos civilizatórios do sistema capitalista não teriam sequer ocorrido. Diz Marx de modo muito claro: "o que melhor poderia caracterizar o modo de produção capitalista do que a necessidade de que lhe sejam impostas, por meio de coação legal do Estado, as mais simples providências de higiene e saúde?" (MARX, 1996 b, p. 110) As mais simples e básicas condições de trabalho precisam ser impostas pelo Estado à produção burguesa, portanto. Ao mesmo tempo, há um segundo aspecto a ser destacado: não há qualquer tendência inabalável ao incremento de direitos sob a ordem capitalista. O processo está relacionado ao incremento do mais-valor relativo em detrimento do absoluto e, em verdade, é necessário que se considere aspectos bastante meandrados sobre o assunto, como a divisão internacional do trabalho, ao analisar a questão. Diz Marx algo essencial sobre isto:

O capital, assim que fica sujeito ao controle do Estado apenas em alguns pontos da periferia social, se ressarce tanto mais desmesuradamente nos outros pontos; segundo, o clamor dos próprios capitalistas por igualdade nas condições de concorrência, isto é, limitações iguais à exploração do trabalho. (MARX, 1996 b, p. 118).

Há um desenvolvimento desigual e combinado no capitalismo, de modo que o processo em que há incremento de direitos (ou seja, de melhores condições de trabalho e de 
educação aos trabalhadores, o que se relaciona à preponderância da extração do maisvalor relativo) não é necessariamente universalizado, e pode se dar às custas de camadas específicas da classe trabalhadora. Se o capital é controlado por meio do Estado e do Direito somente em alguns pontos, tem-se que ele coloca, noutras localidades, uma ofensiva em que "se ressarce tanto mais desmesuradamente em outros pontos". E, também neste sentido, há de se perceber, de um lado, a subordinação existente entre a atuação estatal, sua efetividade e o movimento econômico; doutro lado, tem-se que somente em condições bastante específicas é que aparecem algo como o incremento dos direitos dos trabalhadores. A própria noção de "jornada normal de trabalho" assim supõe, de modo que o papel ativo do Direito e do Estado está subordinado às próprias condições de produção capitalistas, embora dependa, ao mesmo tempo, das lutas diuturnas da classe trabalhadora.

Este elemento contraditório da produção capitalista faz com que, ao mesmo tempo, o Estado apareça como um resumo das contradições da sociedade civil-burguesa e subordine-se à existência desta própria sociedade. No livro I de O capital, também, tal aspecto é bastante saliente.

\section{ESTADO, MOEDA, ENDIVIDAMENTO E PRODUÇÃO CAPITALISTA}

Uma questão bastante óbvia, mas que precisa ser destacada é: a rigor, o próprio curso forçado da moeda depende do Estado, embora não seja por este, em última instância determinado. O dinheiro, com função de meio circulante ou de moeda, passa, simultaneamente, pelo modo pelo qual tem-se, inclusive, uma autonomia relativa diante de sua base metálica. Diz Marx que "bilhetes de papel que levam impressos denominações monetárias, como 1 libra esterlina, 5 libras esterlinas etc., são lançados de fora pelo Estado no processo de circulação." (MARX, 1996 a, p. 248) Nesse processo, ao mesmo tempo, o Direito e o Estado são essenciais e não determinam por si sós o movimento econômico. Em uma famosa passagem da Miséria da filosofia, diz Marx: "o ouro e a prata só são aceitáveis de direito porque o são de fato, e o são de fato porque a organização atual da indústria necessita de um agente universal de troca. O Direito não é mais que o reconhecimento oficial do fato." (MARX, 1989, p. 86) Ou seja, mesmo no que toca os metais preciosos, tem-se que estes não figuram como agente universal de troca por causa da ordem jurídica ou estatal. Antes, o Direito só reconhece aquilo que já está colocado nas próprias potencialidades que fazem parte da faticidade. Tanto no caso dos metais preciosos funcionando como agente de troca, quanto no caso do curso forçado de moeda, o Direito (e a política) têm um papel ativo bastante evidente. No entanto, segundo Marx, a compreensão do processo social que depende do elemento jurídico e estatal não pode ser explicado a partir deles mesmos. Antes, "a totalidade destas relações de produção constitui a estrutura econômica da sociedade, a base real sobre a qual se eleva uma superestrutura jurídica e política e à qual correspondem formas sociais determinadas de consciência. $O$ modo de produção da vida material condiciona o processo de vida intelectual, político e social." (MARX, 2009. p. 47) Há de se ter em conta, ao mesmo tempo, de um lado, o papel ativo do Direito e do Estado, doutro lado, a dependência real diante da totalidade das relações de produção.

A questão se relaciona também à autonomia relativa das esferas econômicas: 
Esse curso forçado pelo Estado rege somente dentro das fronteiras de uma comunidade ou na esfera interna de circulação, mas também somente aqui o dinheiro reduz-se totalmente à sua função de meio circulante ou de moeda, e pode, portanto, receber na moeda papel uma modalidade de existência puramente funcional e exteriormente separada de sua substância metálica. (MARX, 1996 a, p. 248).

Somente com o papel ativo do Estado e do Direito é possível que exista o papel-moeda como uma forma autônoma diante dos metais preciosos. A questão pode parecer lateral, mas não é. Justamente com o papel-moeda e com o divórcio entre a base material de medida de valor (os metais preciosos, em Marx) e a representação deste tem-se a possibilidade de algo como o sistema de crédito, bem como de imbrincados sistemas de investimento capitalista, como as sociedades por ações. Viu-se, assim, que o papel ativo do Estado na autonomização das formas econômicas é de grande relevo; no caso, temse a conformação da autonomia relativa do papel-moeda diante tanto dos metais preciosos quanto da medida do valor, a saber, o tempo de trabalho socialmente necessário. A questão tem diversas nuances, que não podem ser trazidas à tona aqui. (Cf. SARTORI, 2019) No entanto, é necessário deixar clara a importância desta autonomização diante da conformação do sistema de crédito público. O tema é tratado no livro I de O capital:

O sistema de crédito público, isto é, das dívidas do Estado, cujas origens encontramos em
Gênova e Veneza já na Idade Média, apoderou-se de toda a Europa durante o período
manufatureiro. O sistema colonial com seu comércio marítimo e suas guerras comerciais
serviu-lhe de estufa. Assim, ele se consolidou primeiramente na Holanda. A dívida do
Estado, isto é, a alienação do Estado - se despótico, constitucional ou republicano -
imprime sua marca sobre a era capitalista. Aúnica parte da assim chamada riqueza nacional
que realmente entra na posse coletiva dos povos modernos é - sua dívida de Estado. Daí
ser totalmente consequente a doutrina moderna de que um povo torna-se tanto mais rico
quanto mais se endivida. O crédito público torna-se o credo do capital. E com o surgimento
do endividamento do Estado, o lugar do pecado contra o Espírito Santo, para o qual não há
perdão, é ocupado pela falta de fé na dívida do Estado. A dívida pública torna-se uma das
mais enérgicas alavancas da acumulação primitiva. Tal como o toque de uma varinha
mágica, ela dota o dinheiro improdutivo de força criadora e o transforma, desse modo, em
capital, sem que tenha necessidade para tanto de se expor ao esforço e perigo inseparáveis
da aplicação industrial e mesmo usurária. Os credores do Estado, na realidade, não dão
nada, pois a soma emprestada é convertida em títulos da dívida, facilmente transferíveis,
que continuam a funcionar em suas mãos como se fossem a mesma quantidade de dinheiro
sonante. (MARX, 1996 b, p. 373 ).

Se "a dívida pública torna-se uma das mais enérgicas alavancas da acumulação primitiva" há de se notar como que a atuação estatal mesma se coloca, novamente, como potência econômica.

No caso, trata-se daquilo que, depois, no livro III, Marx veio a chamar de capital fictício. Então, o divórcio entre a base metálica e a representação do valor é bastante gritante. Por mais que, segundo Marx, este elo não possa ser real e efetivamente rompido, temse, no capital fictício, com a mediação de transações jurídicas, uma forma de aparição do valor que parece ser absolutamente dissociada do processo produtivo. No que, neste ponto, há de se mostrar que, de acordo com o autor de $O$ capital, tal aparência só é trazida como tal ao passo que é impossível que não exista uma base real - ancorada na produção material - para o capital fictício. No caso, isto fica claro já que o próprio processo de "alavancamento" da acumulação primitiva não prescinde de um papel central da dívida pública. Deste modo, na "assim chamada acumulação primitiva" - como, aliás, durante toda a produção capitalista - não se tem tanto o entesouramento mais ou 
menos idílico como um preâmbulo da acumulação de capital. Antes, a violência estatal de um lado, e as transações jurídicas que conformam o elo necessário à formação da dívida pública doutro, são o liame para a liberação das potências econômicas presentes na faticidade da realidade efetiva da sociedade capitalista.

É interessante notar como que, segundo Marx, formas econômicas pré-capitalistas como os juros, o dinheiro, ou mesmo as dívidas do Estado - passam a se subordinar à reprodução do capital tão logo este se coloca sobre os próprios pés. No caso que tratamos, há de se ver como que o sistema de crédito público (que teria origem em Gênova e em Veneza na Idade Média) tem um papel ativo bastante relevante na medida em que, segundo Marx, "a dívida do Estado, isto é, a alineação (Veräusserung) do Estado - se despótico, constitucional ou republicado - imprime sua marca sobre a era capitalista." Ou seja, a preparação de um capitalismo que se coloca sobre os próprios pés, bem como a reprodução diuturna do sistema capitalista, depende do Estado, ao mesmo tempo em que não tem suas raízes no "céu político"; tanto guerras comerciais quanto o colonialismo têm raízes econômicas bastante marcantes. Assim, é equivocado tanto desconsiderar as especificidades políticas de cada época quanto deixar de perceber as raízes econômicas dos fenômenos políticos. Não há uma forma política "igualmente compatível com todas as formas econômicas da sociedade" e também não se tem como desconsiderar o efeito ativo do Estado e do Direito - efeito este sempre, até certo ponto, distinto em épocas e modos de produção diferentes.

No que toca nosso tema, é importante destacar que a acumulação de riqueza a ser investida de modo mais ou menos mediano no processo produtivo - ou seja, a acumulação de capital - não é trazida pela acumulação do burguês diligente, mas vem da "riqueza nacional que efetivamente entra na posse coletiva dos povos modernos", "a dívida do Estado". Marx, diz que, no limite, é verdade que "um povo torna-se tanto mais rico quanto mais se endivida". E o fetichismo do capital fictício aparece de modo bastante destacado neste ponto: tanto "o crédito público torna-se o credo do capital", "o lugar do pecado contra o Espírito Santo [... e é ocupado pela falta de fé da dívida do Estado". Ou seja, na medida mesma em que o endividamento público passa pelo capital fictício e pela autonomização das formas econômicas - que precisa da mediação estatal para se colocar como tal - ele tem uma função ativa no alavancamento da acumulação primitiva. Diz Marx, neste sentido: "tal como o toque de uma varinha mágica, ela dota o dinheiro improdutivo de força criadora e o transforma, desse modo, em capital, sem que tenha necessidade para tanto de se expor ao esforço e perigo inseparáveis da aplicação industrial e mesmo usurária." Para que parodiemos Hegel, há de se perceber que justamente na medida de sua irracionalidade - ou seja do fato de não se bastar, de precisar ser explicado a partir de um processo que lhe é externo - o endividamento é efetivo em meio à realidade do capitalismo em consolidação. (Cf. SARTORI, 2019) No que diz respeito ao tema que tratamos aqui, ainda há de se pontuar: tal questão é, até certo ponto, indiferente à forma de governo adotada pelos Estados específicos ("se despótico, constitucional ou republicado"); também aqui, portanto, a política tem um papel central na conformação do processo econômico mesmo. Ao mesmo tempo, ela é subordinada às possibilidades presentes na própria realidade efetiva das relações econômicas. Ou seja, mesmo que sem a atuação estatal os fenômenos sociais capitalistas não possam se conformar como tais, a política nunca ultrapassa a sociabilidade que lhe dá base.

Diz o autor de $O$ capital que a conformação do capital fictício passa pelo fato de que "os credores do Estado, na realidade, não dão nada, pois a soma emprestada é convertida 
em títulos da dívida, facilmente transferíveis, que continuam a funcionar em suas mãos como se fossem a mesma quantidade de dinheiro sonante." Assim, a "riqueza nacional que efetivamente entra na posse coletiva dos povos modernos" cumpre um papel ligado ao alavancamento da acumulação primitiva. Destacamos o tema porque a questão remete a assuntos bastante prosaicos, como a tributação:

Como a dívida do Estado se respalda nas receitas do Estado, que precisam cobrir os juros e demais pagamentos anuais, o moderno sistema tributário tornou-se um complemento necessário do sistema de empréstimos nacionais. Os empréstimos capacitam o governo a enfrentar despesas extraordinárias, sem que o contribuinte o sinta imediatamente, mas exigem, ainda assim, como consequência, elevação de impostos. Por outro lado, o aumento de impostos causado pela acumulação de dívidas contraídas sucessivamente força o governo a tomar sempre novos empréstimos para fazer face a novos gastos extraordinários. O regime fiscal moderno, cujo eixo é constituído pelos impostos sobre os meios de subsistência mais necessários (portanto, encarecendo-os), traz em si mesmo o germe da progressão automática. A supertributação não é um incidente, porém muito mais um princípio. (MARX, 1996 b, p. 375).

Há de se notar que, para Marx, a tributação não está ligada à ideia de Estado, relacionada a alguma espécie de "bem comum"; em verdade, o "regime fiscal moderno" só poderia remeter à conformação do sistema capitalista de produção. O processo de "acumulação primitiva", que traz o modo de produção capitalista das entranhas do sistema feudal, tem consigo o endividamento estatal, que, por sua vez, traz o pagamento de juros devidos (tanto em títulos da dívida pública quanto em outros casos). E, assim, do próprio processo pelo qual o capitalismo se coloca sobre os próprios pés surge a necessidade de um sistema tributário específico. Ao passo que a "riqueza nacional que efetivamente entra na posse coletiva dos povos modernos" se destaca, aumenta o endividamento dos Estados. Estes, por sua vez, trazem como algo contraposto a esta tendência tanto uma atitude predatória diante do moderno colonialismo quanto o "regime fiscal moderno". Tais tendências estariam na própria estrutura do sistema capitalista.

Marx, assim, coloca o papel ativo do Estado - por meio da tributação - como algo inerente à própria gênese e ao próprio desenvolvimento do sistema capitalista. E é interessante notar que isto se dá, inclusive, na medida em que o "regime tributário moderno" tem características classistas bastante evidentes: em vez de os tributos recaírem sobre aqueles que tem maior capacidade de pagamento, maior "capacidade contributiva" (no caso, as diversas camadas burguesas), eles recaem sobre os bens de consumo das classes populares. Diz o autor de $O$ capital que o regime de tributação moderno traz um papel "cujo eixo é constituído pelos impostos sobre os meios de subsistência mais necessários (portanto, encarecendo-os)". Sobre isto, deve-se trazer dois aspectos importantes: de um lado, tem-se o Direito tributário operando no Estado ao trazer a acumulação de riqueza, que poderia ser investida, de um modo mais ou menos mediado, na produção. Assim, o sistema moderno de tributação funciona também como uma alavanca da acumulação primitiva. De outro lado, porém, deve-se lembrar que o aumento do custo dos "meios de subsistência mais necessários" recai também indiretamente sobre a burguesia, já que o custo e a reprodução da mercadoria força de trabalho torna-se mais cara. As contradições do processo são claras.

Aqui, como noutros pontos de nosso texto, fica clara a evidência: não há como desconsiderar o solo sobre o qual se coloca o papel ativo do Estado e do Direito modernos, aquele da reprodução ampliada do sistema capitalista. As contradições deste sistema aparecem de modo pungente também: se em um primeiro momento, a 
produção pode avançar com uma relação predatória e espoliativa sobre a classe trabalhadora, isto não tem como ser assim sempre. Isto depende do desenvolvimento e das contradições deste modo de produção. Em um momento em que se expande o mais-valor absoluto, tal solução - ligada a um sistema tributário absolutamente regressivo - coloca-se como ideal. No entanto, a desvalorização dos "meios de subsistência mais necessários" também é algo essencial para que se consiga elevar o mais-valor relativo. Também neste ponto, é válido o que dissemos antes: a compreensão do papel ativo do Estado e, no caso, do Direito tributário, de um lado, remete aos antagonismos classistas, certamente. No entanto, também se tem uma relação bastante íntima com a fase de desenvolvimento das contradições do sistema capitalista. Assim como no caso da regulamentação fabril, aqui não há como ver a conquista de avanços - trazidos, por exemplo, no sistema progressivo de taxação, na "progressão automática" - como algo que, no desenrolar do avanço das forças capitalistas, possa ser mantido independentemente das condições. Também se tem conquista de concessões dentro do próprio modo de produção capitalista. Aqui, no entanto, não podemos tratar da questão com cuidado.

Vale destacar, porém, que algo como a supertributação não é meramente algo de menor importância ao sistema capitalista. Antes, tem-se o oposto, tanto na gênese deste modo de produção quanto ao se considerar seu meandrado desenvolvimento: "a supertributação não é um incidente, porém muito mais um princípio." A questão também ganha destaque pois remete à divisão internacional do trabalho e, portanto, por vias reflexas, para o colonialismo: "com as dívidas do Estado surgiu um sistema intemacional de crédito, que frequentemente oculta uma das fontes da acumulação primitiva neste ou naquele povo." (MARX,1996 b, p. 374) Justamente a espoliação de um povo por outro pode "ocultar" fontes necessárias para o processo de consolidação do modo de produção capitalista. Isto, inclusive, remete para esta relação no que toca o desenvolvimento do capitalismo em seu desenvolvimento desigual e combinado. No entanto, tratar de tal tema escaparia àquilo que é trazido no livro I de $O$ capital, restando a nós somente destacar que o texto de Marx traz elementos bastante importantes para a análise do sistema capitalista como um todo.

\section{MoNOPÓlIOS LEGAIS, BANCOCRACIA E O PAPEL ATIVO DO ESTADO}

A trama traçada por Marx ao analisar questões que passam pelo papel ativo da política e do Direito é bastante complexa. Nela estão também as sociedades por ações. Por mais que estas, bem como a financeirização da economia, apareçam sobretudo no livro III de O capital, também há anotações importantes no livro I. Antes de trazer à tona esta questão, no entanto, vale fazer uma nota sobre algo bastante relacionado ao que tratamos acima: se antes, analisamos a relação da conformação do sistema capitalista com a modema tributação e com o colonialismo, destacamos o modo desigual pelo qual o modo de produção capitalista se entifica. Aqui, aparece uma temática bastante relacionada ao tema, a questão racial. Diz Marx em sua obra magna que:

Nos Estados Unidos da América do Norte, todo movimento operário independente ficou paralisado enquanto a escravatura desfigurava uma parte da República. O trabalhador de pele branca não pode emancipar-se onde o trabalhador de pele negra é marcado com ferro em brasa. Mas da morte da escravidão nasceu imediatamente uma vida nova e rejuvenescida. O primeiro fruto da guerra civil foi a agitação pelas 8 horas, que se propagou com as botas de sete léguas da locomotiva do Atlântico ao Pacífico, de Nova Inglaterra até a Califórnia. (MARX, 1996 a, p. 413). 
O desenvolvimento desigual coloca-se também dentro dos próprios limites nacionais. Trata-se de algo semelhante a uma espécie de colonialismo intemo. Com a exploração da escravidão, o próprio movimento operário independente teria ficado paralisado. Justamente com algo que "desfigurava parte da república", com "o trabalhador de pele negra marcado com ferro e brasa", bloqueia-se a emancipação da classe trabalhadora. Assim, se o endividamento estatal, bem como o sistema tributário modemo, caminham juntos com o colonialismo, há de se notar que a própria escravidão moderna anda também lado a lado com o desenvolvimento do desenvolvimento desigual e combinado que permeia a evolução do sistema capitalista. Assim como no caso do trabalho infantil e da relação predatória com a mercadoria força de trabalho, não há uma relação necessária com a produção deste modo de produção. No entanto, resta a possibilidade.

A questão diz respeito a nosso tema devido a dois aspectos. Primeiramente porque o elemento, por assim dizer, "externo" da atividade estatal (a guerra) está envolvida com tal aspecto. Justamente com a guerra civil americana é que foi possível a vitória do norte sobre o sul e a consequente abolição da escravidão. Em segundo lugar, porém, há de se ressaltar que a regulamentação das horas de trabalho - em que a mediação jurídica é essencial - só pode vir aos EUA com força ao passo que "da morte da escravidão nasceu imediatamente uma vida nova e rejuvenescida. O primeiro fruto da guerra civil foi a agitação pelas 8 horas". Ou seja, novamente, tem-se aqui a explicitação da base real daquilo que pode ser visto como a conquista de direitos por parte da classe trabalhadora. Vê-se, também, o modo pelo qual, ao mesmo tempo, tem-se a luta de classes aparecendo em meio ao movimento da própria produção capitalista, e não pairando no ar.

\begin{abstract}
Conforme se viu: essas determinações minuciosas, que regulam o período, limites, pausas no trabalho de modo tão militarmente uniforme de acordo com o bater do sino, não eram, de modo algum, produto de alguma fantasia parlamentar. Desenvolveram-se progressivamente das próprias circunstâncias, como leis naturais do modo de produção moderno. Sua formulação, reconhecimento oficial e proclamação pelo Estado foram o resultado de prolongadas lutas de classes. Uma de suas consequências mais imediatas foi submeter, na prática, a jornada de trabalho dos operários masculinos adultos aos mesmos limites, uma vez que a cooperação das crianças, dos adolescentes e das mulheres era imprescindível na maioria dos processos de produção. (MARX, 1996 a, p. 396).
\end{abstract}

O elemento dúplice da conquista de direitos aparece de modo claro. Ao mesmo tempo em que se conquistam concessões, estas aparecem, até certo ponto, sob o solo das "leis naturais do modo de produção moderno". O papel ativo do Estado e do Direito passa, assim, por um duplo reconhecimento: da luta dos trabalhadores, e destes trabalhadores enquanto homens e mulheres cuja forma de aparição resume-se a indivíduos assalariados. Aquilo que está em jogo, pois, não é a supressão do assalariamento, mas o modo mais ou menos espoliativo de lidar com a mercadoria força de trabalho. Neste ponto, é preciso dizer: as lutas de classe ocorrem em meio às contradições e especificidades das diferentes esferas do capital. Estas, por sua vez, podem se colocar, em sua autonomização - que depende da atividade do Estado e da regulamentação jurídica - de modo bastante irracional. Se é verdade que a emergência mesma do capitalismo depende do endividamento estatal, do crédito e das sociedades por ações, igualmente verdadeiro é que "a dívida do Estado fez prosperar as sociedades por ações, o comércio com títulos negociáveis de toda espécie, a agiotagem, em uma palavra: o jogo da Bolsa e a moderna bancocracia." (MARX, 1996 b, p. 374) O desenvolvimento da grande indústria é indissolúvel da emergência do "jogo da bolsa", bem como da "moderna bancocracia". Assim, deve-se destacar que mesmo que Marx vá tratar destes 
assuntos com mais cuidado sobretudo no livro III de O capital, o tema já aparece no livro I de sua grande obra econômica. E, tal qual nos outros casos, o papel do Direito e do Estado aqui é bastante destacado, ao mesmo tempo em que há uma dependência clara diante de uma sociabilidade específica e das contradições que se colocam em meio ao desenvolvimento do sistema capitalista.

No que, neste ponto, Marx trata, inclusive, da necessidade do investimento estatal. Ao tratar do início do capitalismo - mas, com as devidas ressalvas, o mesmo seria válido para uma fase mais avançada - diz o autor sobre os monopólios legais e sobre as sociedades por ações:

O mínimo da soma de valor que deve dispor um possuidor individual de dinheiro ou de
mercadorias para metamorfosear-se em capitalista varia em diferentes graus de
desenvolvimento da produção capitalista e, dado o grau de desenvolvimento, é diferente nas
diferentes esferas de produção, conforme as condições técnicas específicas de cada uma.
Certas esferas de produção exigem já nas primeiras etapas da produção capitalista um
mínimo de capital que ainda não se encontra em mãos de indivíduos isolados. Isso leva, em
parte, o Estado a subsidiar tais particulares, como na França no tempo de Colbert e em
alguns Estados alemães até a nossa época, em parte à constituição de sociedades com
monopólio legal para explorar determinados ramos industriais e comerciais - as
precursoras das modernas sociedades por ações. (MARX, 1996 a, p. 423 ).

Mesmo que a "assim chamada acumulação primitiva" não se dê primordialmente com investimentos individuais, no desenrolar do capitalismo, estes são necessários (e, aqui, entraria em campo um tema bastante importante para o livro III de O capital, o capital portador de juros). Os capitalistas, porém, não conseguem sempre realizar esta tarefa isto varia de acordo com "os diferentes graus de desenvolvimento da produção capitalista" -, de modo que, segundo Marx, é necessária a intervenção de um terceiro, no caso, o Estado. Ele pode tanto se colocar no campo da produção com subsídios (seja via crédito barato, seja com desonerações tributárias ou por meio dos outros artifícios) quanto mais diretamente, com empresas estatais ou com "sociedades com monopólios legais". Marx, assim, parece destacar o papel que a intervenção estatal, bem como a regulamentação jurídica tem no investimento em meio ao sistema capitalista.

No entanto, a questão é mais complexa porque, justamente, não é necessário que tal investimento se coloque diretamente por meio do Estado. Há também a possibilidade das sociedades por ações se colocarem em um papel central quando "o mínimo da soma de valor que deve dispor um possuidor individual de dinheiro ou de mercadorias para metamorfosear-se em capitalista varia" tanto de acordo com "diferentes graus de desenvolvimento da produção capitalista" quanto em relação a "diferentes esferas da produção". O papel do Estado, nestes ramos, pode, inclusive, modificar-se em meio ao desenvolvimento capitalista. Pode, por exemplo, figurar como um detentor do monopólio legal em um primeiro momento para que, depois, sejam sociedades privadas que exerçam o mesmo papel antes desenvolvido pela empresa estatal; depois que o investimento originário é colocado por meio do endividamento estatal e com maciço montante de capital investido, é possível que o negócio seja lucrativo a tal ponto que possa interessar aos capitalistas que, tão logo quanto possível, buscariam romper com o monopólio legal e desenvolver sociedades por ações, por exemplo. Ou seja, tanto o papel ativo do Estado e do Direito tem uma base sólida nas contradições da sociedade capitalista que, depois de determinado grau de desenvolvimento, surge a possibilidade de aquilo que fora exercido politicamente colocar-se por meio de uma somatória de capitalistas que, segundo Marx, colocam-se como uma espécie de "capitalista coletivo". 
Assim, se é verdade que, nos momentos primevos do sistema capitalista ainda existia uma regulamentação corporativa e ligada aos interesses dos artesãos ${ }^{19}$, a questão muda substancialmente. No limite, chega-se a um papel bastante destacado tanto da "bancocracia" quanto das sociedades por ações que passam a exercer o papel que, em meio à acumulação primitiva coube ao Estado. Destacamos a questão porque, se é verdade que a atividade estatal pode se colocar como uma potência econômica, devese perceber que as forças econômicas mesmas, por vezes - claro, por meio da regulamentação jurídica estatal - podem exercer esta tarefa de modo imediato.

\section{CONCLUSÃo}

Vimos, portanto, o modo pelo qual Marx trata do papel ativo do Estado e do Direito em meio ao livro I de $O$ capital. A questão apareceu de modo bastante meandrado, já que a função realizada politica e juridicamente teve uma importância decisiva, ao mesmo tempo em que não prescindia das bases materiais colocadas em meio ao desenvolvimento - mais ou menos avançado - da própria produção capitalista. A questão passa pela luta de classes, certamente, mas esta última se dá em meio a diferentes fases da produção capitalista e tendo em conta contradições bastante bem delineadas. Não se trata, para Marx, portanto, de enxergar as conquistas da classe trabalhadora como o simples resultado de sua vontade combativa; antes, há de se ver como que a resistência à imposição do capital se dá, até certo ponto, dentro do próprio terreno do capital, em que a regulamentação fabril, a tributação progressiva e outros mecanismos podem favorecer os trabalhadores ao mesmo tempo em que dependem do desenvolvimento das contradições capitalistas. Diz Marx sobre a questão que "sua formulação, reconhecimento oficial e proclamação pelo Estado foram o resultado de prolongadas lutas de classes." Assim, percebemos que tal luta tem limites na própria objetividade da produção, de modo que não basta "vontade política" para ir "mais longe".

Em verdade, os arranjos da produção capitalista são bastante complexos e as contradições deste modo de produção são essenciais para que se perceba a maneira pelo qual o Direito e o Estado têm um papel ativo. Este papel pode ser exercido tanto trazendo direitos aos trabalhadores em meio ao processo de extração de mais-valor (no caso, vimos que há bastantes diferenças entre o momento em que prevalece a extração de mais-valor absoluto e relativo) quanto ao passo que a função do capitalista individual é cumprida pelo Estado. Ou seja, a simples intervenção em meio à livre concorrência não garante qualquer ganho à classe trabalhadora. Em verdade, na maioria dos casos, é algo que alavanca a sua exploração. Por isso, Marx enfatiza no livro I de O capital o modo pelo qual o elemento político e jurídico são essenciais à implementação, mas também à simples reprodução diuturna do capital. Ele mostra como que esta intervenção está subordinada a possibilidades presentes na faticidade da própria sociabilidade capitalista. A regulamentação jurídica, bem como a atuação estatal pressupõem de um modo mais ou menos mediado a relação-capital e, para o autor, em verdade, seria necessário o momento em que "soa a hora final da propriedade privada capitalista. Os

\footnotetext{
${ }^{19}$ Diz Marx sobre a relação entre corporações e capital comercial: "as leis das corporações, conforme já observamos, impediam planejadamente, ao limitar com severidade o número de ajudantes que um único mestre de corporação podia empregar, a sua transformação em capitalista. Da mesma forma, somente era-lhe permitido empregar ajudantes no ofício em que ele era mestre. A corporação defendia-se zelosamente contra qualquer intrusão do capital mercantil, a única forma livre de capital, com que se defrontava. O comerciante podia comprar todas as mercadorias, mas não o trabalho como mercadoria. Ele era apenas tolerado como distribuidor dos produtos artesanais." (MARX, 1996 a, p. 473)
} 
expropriadores são expropriados." (MARX, 1996 b, p. 381) Por mais que a questão que aqui tratamos - relacionada ao papel da política e do Direito - seja essencial para a compreensão do próprio capitalismo, segundo Marx, até certo ponto, ela é secundária ao se tratar daquilo que ele defende, relativo à supressão do próprio assalariamento e da sociedade civil-burguesa. Também em $O$ capital, portanto, resta, não tanto uma posição elogiosa quanto à politicidade, mas uma crítica ao Estado e ao Direito. Para o autor alemão, compreender a importância destes, ao mesmo tempo, é essencial e remete à necessidade da crítica a eles e àquilo que lhes dá base. Esta é a posição presente no livro I da obra magna do autor alemão.

Tal aspecto fica claro ao autor na medida em que diz que as condições mais básicas de higiene e de convívio precisam ser impostas pelo Estado ao capital; ao mesmo tempo, tem-se que a limitação local da regulamentação fabril faz com que seja possível, inclusive, um incremento na exploração da força de trabalho noutros locais. Ou seja, o elemento jurídico e estatal precisa ser tratado dentro das limitações do modo de produção capitalista, o que envolve considerar diversos elementos, como o moderno colonialismo, a questão racial, o grau de exploração do trabalho (ligado à extração de mais-valor relativo e absoluto) bem como a possibilidade de investimento inicial por parte dos capitalistas individuais. A tais elementos, ligam-se a conquista de direitos e um modo mais ou menos progressista de se relacionar com o capitalismo. $\mathrm{E}$, para Marx, isso é claro: com o modo de produção capitalista, pode-se oscilar entre um polo e outro destas posições, mas não se pode ir à raiz da questão. Aqui também é válido o que foi dito noutro lugar, e que foi bastante enfatizado pelo filósofo brasileiro José Chasin ao tratar da obra marxiana: "o princípio da política é a vontade. Quanto mais unilateral, isto é, quanto mais ele crê na onipotência da vontade e tanto mais é cego frente aos limites naturais e espirituais da vontade e, consequentemente, tanto mais é incapaz de descobrir a fonte dos males sociais." (MARX, 2010 b, p. 62).

\section{REFERÊNCIAS}

ALVES, Antônio José Lopes. Marx e a analítica do capital. Saärbruken: Novas edições acadêmicas, 2012. CLAUDIN, Fernando. A crise o movimento comunista. Trad. José Paulo Netto. São Paulo: Expressão popular, 2013.

CHASIN, José. Marx: Estatuto Ontológico e Resolução Metodológica. São Paulo: Boitempo, 2009.

CHASIN, José. O integralismo de Plínio Salgado: forma de regressividade no Capitalismo Hipertardio. São Paulo: Ciências Humanas, 1978.

EDELMAN, Bernard. A legalização da classe operária. Trad. Flávio Roberto Baptista. São Paulo: Boitempo, 2016.

EDELMAN, Bernard. O Direito captado pela fotografia. Trad. Soveral Martins e Pires de Carvalho. Coimbra: Centelho, 1976.

HARVEY, David. O enigma do capital: e as crises do capitalismo. Trad. João Alexandre Peschanski. São Paulo: Boitempo, 2011.

HARVEY, David. O novo imperialismo. Trad. Adail Sobral e Maria Stela Gonçalves. São Paulo: Loyola, 2005.

HARVEY, David. Para entender O capital. Trad. Rubens Enderle. São Paulo: Boitempo, 2013.

LENIN, V.I. O desenvolvimento do capitalismo na Rússia. Trad. José Paulo Netto. São Paulo: Abril Cultural, 1982. 
LUKÁCS, György. El Asalto a la Razón. Trad. Wenceslau Roces. México: Fondo de Cultura Econômica, 1959.

LUKÁCS, György. Ontologia do ser social I. Trad. Carlos Nelson Coutinho, Mario Duayer e Nélio Schneider. São Paulo: Boitempo, 2012.

LUXEMBURGO, Rosa. A acumulação de capital. Trad. Muniz Bandeira. Rio de Janeiro: Zahar, 1970.

MARX, Karl. Contribuição à Crítica da Economia Política. Trad. Florestan Fernandes. São Paulo: Expressão Popular, 2009.

MARX, Karl. Formações econômicas pré-capitalistas. Trad. João Maia. Rio de Janeiro: Paz e terra, 1985.

MARX, Karl. Glosas críticas marginais ao artigo "O rei da Prússia e a reforma social": de um prussiano (1844). Trad. Ivo Tonet. São Paulo: Expressão Popular, 2010 b.

MARX, Karl. Grundrisse. Trad. Mario Duayer. São Paulo: Boitempo, 2011.

MARX, Karl. Miséria da filosofia. Trad. José Paulo Netto. São Paulo: Global, 1989,

MARX, Karl. Nova Gazeta Renana. Trad. Lívia Cotrim. São Paulo: Educ, 2010 a.

MARX, Karl. O Capital, Livro I, Volume I. Trad. Regis Barbosa e Flávio R. Kothe São Paulo: Nova Cultural, 1987.

MARX, Karl. O Capital, Livro I, Volume I. Trad. Regis Barbosa e Flávio R. Kothe São Paulo: Nova Cultural, 1996 a

MARX, Karl. O Capital, Livro I. Trad. Rubens Enderle. São Paulo: Boitempo, 2013.

MARX, Karl. O Capital, Livro I, Volume II. Trad. Regis Barbosa e Flávio R. Kothe São Paulo: Nova Cultural, 1996 b.

MARX, Karl. Teorias da mais-valia. Trad. Reginaldo Sant'Anna. São Paulo: Civilização brasileira, 1980.

MARX, Karl; ENGELS, Friedrich. A luta de classes na Rússia. Trad. Nélio Schneider. São Paulo: Boitempo, 2013.

MARX, Karl; ENGELS, Friedrich. Acerca del colonialismo. Trad. editorial progresso. Buenos Aires: Terramar Ediciones, 2009.

MARX, Karl; ENGELS, Friedrich. Manifesto comunista. Trad. Isa Tavares. São Paulo: Boitempo, 1998.

MELOSSI, Dario; PAVARINI, Massimo. Cárcere e Fábrica. Trad. Sérgio Laramão. Rio de Janeiro: Instituto Carioca de Criminologia, 2004.

RUSCHE, Georg; KIRCHHEIMER, Otto. Punição e estrutura social. Trad. Gizlene Neder. Rio de Janeiro: Instituto Carioca de Criminologia, 2006.

SARTORI, Vitor Bartoletti. Fetichismo, transações jurídicas, socialismo vulgar e capital portador de juros: o livro III de O capital diante do papel ativo do Direito. In: Revista da sociedade brasileira de economia política. Rio de Janeiro: Uff, 2019 (No prelo).

Data da submissão: 11/01/2021.

Data da aprovação: 28/04/2021. 